\title{
ЭкСпертизд
}

УДК 502.14

ГУРЛЕВ Игорь Валентинович - доктор технических наук, главный научный сотрудник Академии управления МВД России (125171, Россия, г. Москва, улица 3. и А. Космодемьянских, 8; gurleff@таil.ru)

\section{ПОЧЕМУ НЕ ОЧИЩАЕТСЯ «СВЯЩЕННЫЙ БАЙКАЛ»?}

Аннотация. В статье автор рассматривает состояние, причины и источники существующих экологических проблем, актуальные вопросы сохранения объекта всемирного природного наследия - озера Байкал, ход выполнения федеральной целевой программы «Охрана озера Байкал и социально-экономическое развитие Байкальской природной территории на 2012-2020 годы».

Ключевые слова: озеро Байкал, объект всемирного природного наследия, пресная вода, загрязнение, федеральная целевая программа

$\mathrm{O}$ зеро Байкал является самым большим и глубоким пресным водоемом нашей планеты. В настоящее время Байкал - объект всемирного природного наследия (ОВПН) ЮНЕСКО. Также Байкал единственный в России географический объект, получивший государственную защиту в виде федерального закона от 1 мая 1999 г. № 94-Ф3 «Об охране озера Байкал», подготовленного по рекомендации ЮНЕСКО. Однако это не спасает Байкал от преступной и хищнической эксплуатации как задолго до принятия данного закона, так и после него.

Федеральный закон «Об охране озера Байкал» должен был решить задачу обеспечения однородных юридических требований для двух субъектов Российской Федерации, находящихся на тот момент в Сибирском федеральном округе, Иркутской области и Республики Бурятия, на землях которых располагается ОВПН - озеро Байкал. В законе дано понятие Байкальской природной территории (БПТ), в состав которой входят озеро Байкал, водоохранная зона, прилегающая к озеру, его водосборная площадь в пределах территории Российской Федерации, прилегающие к Байкалу особо охраняемые природные территории (ООПТ), а также прилегающая к озеру территория шириной до 200 км на запад и северо-запад от него. В соответствии с распоряжением Правительства РФ от 05.03.2015 г. № 368 «Об утверждении границ водоохранной и рыбоохранной зон озера Байкал» водоохранной зоной Байкала считается береговая полоса шириной 500 м от уреза воды, однако многие населенные пункты расположены практически у самого уреза.

С 1960-х гг. Байкал активно используется в гидроэнергетике Иркутской и Братской, а с 1980-х гг. - и Усть-Илимской ГЭС в качестве одной из составных частей водохранилища Ангарского каскада. Как следствие этого, уровень воды в озере вырос и привел к затоплению прибрежных лесов, разрушению горных пород и наступлению береговой зоны на сотни метров от своего естественного расположения, что привело к сокращению уловов, измельчению омуля и др. Необходимо отметить, что колебания уровня воды как в сторону повышения, так и понижения отрицательно влияют на экосистему озера.

Крупнейшим негативным воздействием на экосистему Байкала стало строительство на южном берегу озера Байкальского целлюлозного завода. Необходимость производства в СССР авиационного корда, который на тот момент выпускался только в США, появилась после войны в связи с бурным развитием реактивной авиации. Начиная с 1954 г. в течение нескольких лет выбирались места на пресноводных источниках воды, где близко бы имелся 
большой запас древесины. В 1959 г. была выбрана территория на берегу Байкала в километре восточнее устья реки Солзан, и в том же году началось строительство завода. Западнее устья Солзана был построен город Байкальск с населением около 17 тыс. чел. Завод с 1966 г. стал выпускать вискозную целлюлозу, а с 1976 г. получил статус Байкальского целлюлозно-бумажного комбината (БЦБК). Важно отметить, что на реке Ангаре уже в 1965 г. стал работать Братский кордно-целлюлозный завод, а с 1980 г. - и Усть-Илимский целлюлозно-бумажный комбинат, которые более чем в 5 раз превосходили по мощности БЦБК, т.е. никакого государственного смысла в строительстве города и целлюлозного производства на берегу Байкала не было.

Деятельность БЦБК на юге озера в первые же 10 лет после пуска и начала сброса недоочищенных стоков в Байкал привела к формированию акватории площадью около 30 кв. км с нарушенным гидрохимическим режимом, загрязнению донных отложений, а также к изменениям гидробиологических и микробиологических характеристик вод. Комбинат по объемам сбрасываемых сточных вод вносил значительный вклад в общее неблагоприятное антропогенное воздействие на прибрежную акваторию. Первый раз БЦБК прекратил свою работу в конце 2008 г., но уже в 2010 г. по решению правительства РФ комбинат вновь стал работать. Окончательно основное производство и варка целлюлозы были остановлены 13 сентября 2013 г.

До настоящего времени территория закрытого производства бывшего БЦБК не рекультивирована: на общей площади около 1 кв. км вокруг территории комбината сохраняются 14 накопителей шлам-лигнина с массой более 6,5 млн т, куда входят также отходы в виде золы от сжигания осадка сточных вод и неиспользованные химикаты. Оптимальные технологии по переработке шламлигнина и других накопленных опасных отходов деятельности БЦБК до настоящего времени не отработаны.

Крупным фактором неблагоприятного воздействия на экосистему Байкала стало строительство Байкало-Амурской железнодорожной магистрали (БАМ). Уже через год после начала работ на северном берегу озера в 1975 г. появился рабочий поселок Северобайкальск, ставший в 1980 г. городом с населением около 30 тыс. чел.

До настоящего времени ни Северобайкальск, ни другие города и поселки на берегах Байкала при постоянном росте численности населения не располагают достаточными по мощности очистными сооружениями, заводами по утилизации мусора и отходов, а только ограничиваются полигонами для сбора и накопления твердых бытовых отходов.

Самым крупным источником пополнения водных запасов Байкала, а также лидером среди всех притоков озера по его загрязнению является река Селенга: по реке ходит много туристических и промышленных судов, загрязняющих акваторию озера; стоки российских и монгольских промышленных предприятий, нефтепродукты, бытовой мусор попадают в русло Селенги и затем переносятся в озеро.

Среди других негативных факторов, влияющих на экосистему озера, необходимо отметить варварскую вырубку леса, браконьерство, проблемы туризма, замусоривание озера и территории вокруг него, а также отсутствие бассейнового подхода, сложности согласования федеральными субъектами вопросов совместного управления природными ресурсами и охраной Байкала.

В последние годы на территориях вокруг Байкала активизировались многочисленные коллективы «трудолюбивых» лесорубов и строителей, а также многочисленные группы «любознательных туристов», являющихся гражданами дружественной КНР. Однако в настоящее время наши соседи не ограни- 
чиваются только потоками туристов, а начинают скупать байкальские земли. Например, уже сейчас более $10 \%$ поселковой земли в поселке Листвянка принадлежит китайцам. При этом новые владельцы земель ведут себя абсолютно по-варварски: буквально перекапывают горы, строят огромные дома, засоряют улицы и земли, нарушают природный ландшафт озера; многочисленные постройки не оборудуются очистными сооружениями, и все продукты жизнедеятельности неминуемо попадают в Байкал, при этом бо́льшая часть земель регистрируется под индивидуальное жилищное имущество, т.е. владельцы никаких налогов не платят.

Туристы из Поднебесной называют озеро «большой китайской мечтой». По словам жительницы Листвянки Софьи Бунтовской, «их гиды, проводя экскурсии по Листвянке, говорят своим туристам, что Байкал временно принадлежит России, а вообще это Северное море китайцев, на котором раньше жили их племена. А ведь они не только говорят, они и делают его своим, абсолютно на законных основаниях, скупая наши земли». Жители Листвянки обращаются с жалобами и в прокуратуру, и к депутатам, однако для граждан Китая это заканчивается лишь мизерными штрафами, и нашествие продолжается. Подобное происходит также на Ольхоне, в Луговом, Зеленом и других населенных пунKTax $^{1}$.

Тем не менее следует отметить, что гости ведут себя так, как им позволяют хозяева: по сообщению пресс-службы Следственного комитета по Иркутской области, в апреле 2018 г. было возбуждено уголовное дело против главы Листвянки А. Шамсутдинова, подозреваемого в незаконной выдаче разрешений на строительство жилых домов в центральной экологической зоне Байкала. Уголовное дело возбуждено по статье «Превышение должностных полномочий, совершенное главой органа местного самоуправления». Чиновнику грозит до 7 лет лишения свободы. На основании выданных чиновником разрешений собственниками на земельных участках производились такие земляные работы, как снятие плодородного слоя почвы, изменение ландшафта, вывоз грунта, а также возводились многоэтажные объекты капитального строительства. К сожалению, это далеко не единственный пример подобной деятельности местных муниципальных чиновников ${ }^{2}$.

Проблема «черных лесорубов», как китайских, так и местных, является следствием социальных проблем региона, а также следствием попустительства чиновников федеральных, региональных и местных уровней, зачастую являющихся участниками преступных схем.

В течение 2018 г. против чиновников лесного хозяйства Иркутской обл. во главе с министром С. Шевердой, его заместителем А. Туги и другими выдвинуты обвинения в превышении служебных полномочий с причинением тяжких последствий экологии БПТ, подлоге, получении взятки и т.П. Преступные посягательства на экологическую сохранность окружающей среды были зафиксированы при противозаконной вырубке лесов вокруг Байкала, нарушении основных правил борьбы с болезнями сельскохозяйственных культур растений и т.д. ${ }^{3}$

Возможно, федеральное и региональное правительства считают лес неисчерпаемым природным ресурсом, однако скорость уничтожения леса превосходит время, необходимое для его восстановления и полноценного обеспечения его экосистемных функций. Варварская вырубка леса в бассейне Байкала является

\footnotetext{
1 https://zen.yandex.ru/media/babr24/kak-kitaicy-zahvatyvaiut-listvianku-5a157b467ddde8e7f96 a432a (проверено 30.10.2019).

2 http://babr24.com/baik/?IDE=175680 (проверено 27.10.2019).

3 https://baikal.mk.ru/politics/2018/09/19/chereda-ugolovnykh-del-porazila-chinovnikov-svyazannykh-slesnoy-otraslyu.html (проверено 27.10.2019).
} 
отчасти государственной политикой, отчасти следствием деятельности «черных лесорубов». Как региону, так и стране в целом взамен бесконтрольного уничтожения леса необходимо стабильное лесное хозяйство, основывающееся на цикличности рубок и восстановлении леса на уже освоенных территориях без затрагивания старых естественных лесов.

Также нельзя обойти стороной такую проблему, как браконьерство на Байкале. Более половины всех видов рыб Байкала являются объектом незаконной охоты. Под угрозой в первую очередь находится байкальский эндемик - омуль, которого при действующем запрете федеральных властей браконьеры вылавливают тоннами. Несмотря на острую необходимость борьбы с браконьерством, решение о полном запрете лова рыбы при существенном уменьшении численности сотрудников рыбнадзора бесперспективно. Вместо запретов необходимо найти другие решения ${ }^{1}$.

Значительный вклад в развитие экономики Иркутской обл. и Республики Бурятия вносит внутренний и международный туризм. К сожалению, значительная часть туристического бизнеса носит незаконный характер и контролируется не государством, а другими структурами. Однако и законный туристический бизнес с точки зрения экологии организован отвратительно. Поселок Листвянка, называемый «воротами Байкала», - самый посещаемый организованными и неорганизованными туристами объект: вдоль дороги на набережной процветает длиннющий рынок по продаже копченного омуля, сига, хариуса и различных сувениров, на пляже разбросан мусор вперемешку с недоеденными продуктами питания, в воде озера в прибрежной зоне плавают разнообразные пластиковые бутылки и пакеты.

Обратной стороной развития туризма является массовое загрязнение береговых и прибрежных зон Байкала. Особенно активно загрязняют мусором территории вокруг Байкала россияне и китайцы. Наиболее аккуратны европейцы, особенно немецкие туристы, которые убирают за собой мусор.

По мнению научного руководителя Байкальского института природопользования СО РАН академика РАН А.К. Тулохонова, «среди многочисленных проблем Байкала следует выделить главную - это бескультурье населения, отсутствие культуры поведения на отдыхе, отсутствие культуры потребления, отсутствие привычки убирать за собой мусор, отсутствие культуры поддержания порядка, - все остальное уже вторично» ${ }^{2}$.

Из-за использования некачественных очистных фильтров или их полного отсутствия в воды Байкала попадают тысячи тонн неочищенных стоков повышенного уровня опасности, содержащих соединения азота и фосфора. Байкал расположен в котловине, окруженной со всех сторон горами, поэтому вся жидкость любого происхождения и состава неминуемо попадает в «славное море».

По словам руководителя общественного проекта «Сохранение озера Байкал» Екатерины Удеревской, «из имеющихся 27 очистных сооружений в полной мере не работает ни одно. И это при том, что у нас по береговой зоне озера находится 159 населенных пунктов» 3 .

Еще одним возбудителем общественных протестов стало строительство в поселке Култук завода по бутилированию байкальской воды. Инвестором строительства выступает ООО «АкваСиб», основным собственником кото-

\footnotetext{
1 https://iz.ru/801078/evgeniia-priemskaia/v-omul-s-golovoi-chto-izmenilos-na-baikale-posle-zapretana-vylov (проверено 27.10.2019).

2 http://vtiform.com/interview/57106/?sphrase_id=11466693 (проверено 30.10.2019).

3 https://sergievgrad.ru/arkhiv/turizm/ekologi-byut-trevogu-baykal-prevrashchaetsya-v-pomoyku/ (проверено 27.10.2019).
} 
рого является Дацинская водная компания с ограниченной ответственностью «Озеро Байкал», зарегистрированная в китайской провинции Хэйлунцзян.

Ранее местные жители провели несколько акций протеста против строительства данного завода на берегу Байкала. Они считают, что если предприятие будет запущено, то оно нанесет экологический ущерб озеру. Председатель правительства РФ Д.А. Медведев 12 марта 2019 г. заявил, что распорядится проверить проект на соответствие самым высоким экологическим стандартам. С апреля 2019 г. работы по строительству завода были приостановлены, но трубы для забора воды, проложенные по льду, по мере таяния опускаются на дно озера.

В настоящее время западный берег Байкала принадлежит Иркутской обл., находящейся в Сибирском федеральном округе, а восточный берег - Республике Бурятия, которая передана в Дальневосточный федеральный округ, что будет значительно затруднять координацию и контроль состояния БПТ, а также осуществление всех природоохранных мероприятий ОВПН - озера Байкал. С точки зрения системного подхода к сохранению экологии озера, возможно, у Байкала должен быть один хозяин?

Для сохранения озера Байкал правительство России предпринимало несколько попыток. Постановлением Правительства России от 25 ноября 1994 г. № 1306 была принята комплексная федеральная целевая программа (ФЦП) «Обеспечение охраны озера Байкал и рациональное использование ресурсов его бассейна (1995-2001 гг.)». Общие финансовые затраты на реализацию программы из разных источников планировались в сумме 1 641,1 млрд руб. в ценах 1994 г. Впоследствии эта ФЦП не финансировалась и была закрыта как бесперспективная.

В рамках ФЦП «Экология и природные ресурсы России (2002-2010 гг.)», утвержденной постановлением Правительства России от 07 декабря 2001 г. № 860, существовала подпрограмма «Охрана озера Байкал и Байкальской природной территории». Тем не менее финансирование и этой подпрограммы за счет средств федерального бюджета также было существенно сокращено, несмотря на то что в ней планировалось выполнение обязательств страны по двум международным конвенциям: по сохранению биоразнообразия озера и по объекту всемирного природного наследия. Однако правительство РФ приняло решение о закрытии в 2005 г. ФЦП «Экология и природные ресурсы России (2002-2010 гг.)» в связи с отсутствием четкой системы целевых показателей и индикаторов, позволявших оценить результативность программы, а также в связи с нецелевым и неэффективным использованием бюджетных средств.

21 августа 2012 г. было принято постановление Правительства России № 847 «О федеральной целевой программе «Охрана озера Байкал и социально-экономическое развитие Байкальской природной территории на 2012-2020 годы», однако в ноябре 2018 г. по итогам аудиторской проверки сотрудники Счетной палаты Российской Федерации (СП РФ) отметили, что за 2015-2017 гг. и 9 месяцев 2018 г. государственные заказчики ФЦП израсходовали на eе peaлизацию 8,4 млрд руб., но экологическая обстановка в районе озера Байкал не только не улучшилась, но и продолжает ухудшаться. В связи с этим СП РФ объявила о возможном провале многомиллиардной программы охраны Байкала.

Главной причиной провала, по мнению СП РФ, стал срыв сроков ввода объектов в эксплуатацию: из 17 запланированных объектов вовремя были введены только 5. Также не было осуществлено одно из ключевых мероприятий программы - ликвидация негативного воздействия отходов, оставшихся от деятельности БЦБК: на эти цели было выделено почти 2,9 млрд руб., но почти все эти деньги в 2016 г. были возвращены в бюджет, за исключением 131 млн руб., 
потраченных на проектную документацию, но и ее теперь по прошествии более 2 лет невозможно использовать, т.к. она нуждается в корректировке.

Более 232 млн руб. были выделены на создание 4 мусорных полигонов (два полигона - в Иркутской обл. и два - в Республике Бурятия), но к настоящему времени не работает ни один.

По оценкам специалистов, не будут убраны до 2021 г. и нефтепродукты, скопившиеся в Бурятии в почве в районе реки Селенги. На проведение этих работ за 5 лет затрачено 1,3 млрд руб. из бюджета, но до сих пор содержание нефтепродуктов в речной воде в 7,7 раз превышает фоновую пробу. В поселке Закаменка, где располагался Джидинский вольфрамо-молибденовый комбинат, стало просто опасно жить, т.к. не ликвидированы последствия его деятельности - химические вещества, содержащиеся в воздухе, приводят к болезням органов дыхания, крови, почек, эндокринной и центральной нервной системы человека.

СП РФ при аудиторской проверке в 2018 г. обратила внимание Минприроды РФ на методы подбора исполнителей по действующей ФЦП, а также отметила, что остатки средств федерального бюджета, не освоенные АО «Росгеология» по госконтрактам, увеличиваются из года в год и эта тенденция сохранилась в 2016-2018 гг.

Конечно же, в Росгеологии признали выявленные СП РФ недостатки и выразили готовность их устранить. «У нас уже есть план мероприятий по компенсации тех отставаний, которые получены по результатам 2018 года. Мы, безусловно, будем наращивать взаимодействие с Федеральным агентством по недропользованию и компенсировать те объемы производственных отставаний, которые на сегодняшний момент есть», - заявил генеральный директор (на сегодня уже бывший) АО «Росгеология» Роман Сергеевич Панов.

Министр С.Е. Донской в октябре 2017 г. назначил АО «Росгеология» единственным подрядчиком работ на 5,9 млрд руб. по ликвидации последствий деятельности БЦБК. Интересно, что проект предыдущего подрядчика - «ВЭБ Инжиниринг», - который в 2016 г., после нескольких лет рассмотрения и экспертиз, Росприроднадзор по Иркутской обл. признал неэффективным, а проект Росгеологии, отличающийся от проекта «ВЭБ Инжиниринг» только наличием технологии термолиза (при отсутствии сведений об успешном тестировании технологии термолиза) получил положительное заключение Росприроднадзора ${ }^{1}$.

В связи с выявленными СП РФ нарушениями было решено направить представления в Минприроды и Минстрой, а также обратиться в Генпрокуратуру России. Кроме того, информационные письма направлены в правительство РФ, в правительства Иркутской обл. и Республики Бурятия.

Комментируя доклад СП РФ о состоянии выполнения ФЦП по Байкалу, доктор экономических наук Никита Кричевский с сарказмом назвал вывод аудиторов о неэффективности программы поспешным. «Программа очень даже эффективна, только не для всех. Впрочем, “на всех” все равно не хватит», написал Н.А. Кричевский в Facebook ${ }^{2}$.

По словам члена Бурятского регионального объединения по Байкалу, члена Российского социально-экологического союза, ассоциированного научного сотрудника кафедры ЮНЕСКО Восточно-Сибирского государственного университета технологий управления Кристиана Анатольевича Ринчикова, с которыми трудно не согласиться, основными и традиционными для нашей страны причинами провала ФЦП «Охрана озера Байкал и социально-экономическое

\footnotetext{
1 https://www.rbc.ru/business/20/11/2017/5a0ee39d9a79473ae3a4142b (проверено 27.10.2019).

2 https://sergievgrad.ru/arkhiv/turizm/ekologi-byut-trevogu-baykal-prevrashchaetsya-v-pomoуku/ (проверено 11.05.2019).
} 
развитие Байкальской природной территории на 2012-2020 годы» стали некомпетентность и коррупция ответственных лиц ${ }^{1}$.

Экологическое состояние Байкала и территорий вокруг него дошло до такой степени, что делом его спасения уже давно должны были заняться прокуроры и другие силовые ведомства, а чтобы их сотрудники не вступали во внеслужебные отношения с местными чиновниками, необходимо ввести на государственном уровне регулярную ротацию кадров по примеру военнослужащих.

Сегодня неравнодушными и небезразличными к судьбе Байкала остаются в основном разве что только граждане страны, которыми создаются новые и продолжающие свою деятельность общественные организации, основной целью которых является защита экологии Байкала, такие как Фонд содействия сохранению озера Байкал, Иркутская общественная организация «Байкальская экологическая волна», Всемирный фонд дикой природы, Гринпис России, Ассоциация «Защитим Байкал вместе» и др.

Однако проблемой этих организаций является нехватка средств на устранение ущерба, причиненного экологии Байкала².

24 марта текущего года в Иркутске прошла акция в защиту Байкала, собравшая, по разным оценкам, от 1 до 3 тыс. чел. Подобные митинги и пикеты прошли в Москве, Санкт-Петербурге, Красноярске, Улан-Удэ и многих других городах России.

На митинге в Иркутске говорили не только о заводе по розливу воды в поселке Култук, но и о вырубке лесов в центральной экологической зоне БПТ, об отсутствии очистных сооружений в населенных пунктах, сбросе мусора и нечистот с многочисленных судов в воду Байкала и др.

Организаторы митингов собрали более 100 тыс. подписей под обращением к президенту России. Граждане страны опять просят президента России в ручном режиме вмешаться: создать общественный совет по вопросам природопользования на БПТ; усилить контроль по запрету многочисленных строек в незатронутых природных территориях; провести оценку влияния стоков на состояние воды в озере; построить новые и реконструировать старые очистные сооружения; взять под особый контроль утилизацию и рекультивацию площадки БЦБК и т.д., т.е., по сути, начать и закончить все невыполненные программы по очистке и охране Байкала.

Однако в конце марта - начале апреля 2019 г. российская и мировая общественность вновь была взбудоражена размещенным на сайте Минприроды проектом внесения изменений в приказ Минприроды от 05.03.2010 № 63. По этому проекту предполагается увеличение норм содержания некоторых химических веществ и соединений в воде и объемов сброса сточных вод в Байкал.

Нынешний руководитель Министерства природных ресурсов и экологии РФ по образованию - нефтяник и уже по призванию является добытчиком, а не защитником природы. Вероятно, по этой причине (и не только) в недрах его аппарата и родился проект внесения изменений в приказ № 63. При таком подходе у чиновников возникает иллюзия решения любых проблем с принятием собственных постановляющих бумаг, по которым сразу все становится просто чудесно: и Байкал можно «спасти», и неосвоенные миллиарды «сэкономить».

При этом обращает на себя внимание мотивировка ведомства: «Необходимость внесения изменений в Приказ 63 вызвана тем, что действующие нормативы допустимого содержания веществ в сточных водах разработаны без учета практической достижимости данных нормативов, а также природного фона, кото-

\footnotetext{
1 https://regnum.ru/news/2529378.html (проверено 27.10.2019).

2 https://ruslo.info/ekologiia/ekologiia-baikala-problemy-zagryazneniya/ (проверено 27.10.2019).
} 
рый в ряде случаев превышает нормативы. Подобная ситуация приводит к неоправданно высоким затратам на строительство и эксплуатацию очистных сооружений в пределах Байкальской природной территории и, таким образом, является причиной роста тарифной нагрузки на население региона и неэффективного расходования бюджетных средств» 1 .

То есть, в Иркутской обл. и в Бурятии ничего в полном объеме не сделано ни по одной из программ: под предлогом санитарных вырубок уничтожаются леса на БПТ, нет работающих и необходимых очистных сооружений, не налажен системный сбор мусора, не работают административно-правовые барьеры и т.п. Ничего существенного не сделано для улучшения экологии Байкала, кроме мотивировки о невозможности «практической достижимости» и пропавших денег. Естественно, постоянно ухудшается природный фон, на основе которого предлагается ввести новые повышенные нормативы. Если это станет недоброй традицией в решении проблем Байкала, то следующим логическим шагом Минприроды будет дальнейший пересмотр нормативов от достигнутого «природного фона».

Свою озабоченность по поводу планируемого министерством пересмотра нормативов по Байкалу уже выразили ученые-экологи Германии, Японии, США, России и других стран.

В письме от 28.03.2019 г. № 15001-15015-1129 на имя министра природных ресурсов и экологии РФ (копия президенту РАН) председатель Научного совета СО РАН по проблемам озера Байкал, председатель СО РАН академик РАН B.Н. Пармон пишет: «Предлагаемые нормативы существенно увеличивают допустимую массу веществ, сбрасываемых со сточными водами в озеро Байкал. <... Это прямо противоречит требованиям Федерального закона от 01.05.1999 № 94 в части статьи 14, определяющей, что предельно допустимый объем сбросов и выбросов вредных веществ ежегодно подлежит обязательному пересмотру в целях уменьшения. <...> Мы прекрасно понимаем, что выполнение жестких экологических требований при очень ограниченных финансовых ресурcax России в настоящее время является затруднительным. Однако детальный научный анализ экологической ситуации озера Байкал, проведенный нашим Научным советом по проблемам озера Байкал в начале этого года, показал возможность активных и не требующих больших финансовых вливаний действий без изменения существующих нормативов».

Далее в письме академик В.Н. Пармон предлагает снять с федерального портала проект приказа Минприроды как не способствующий сохранению объекта всемирного наследия ЮНЕСКО - озера Байкал для дальнейшей его доработки и прохождения государственной экологической экспертизы и говорит о своей готовности принять активное и конструктивное участие в доработке приказа Минприроды. В приложении к письму приведены статьи двух федеральных законов «Об экологической экспертизе» от 23.11.1995 № 174-Ф3 (ред. от 01.01.2019) и «Об охране озера Байкал» от 01.05.1999 № 94-Ф3, которым противоречат предлагаемые поправки проекта приказа Минприроды.

При этом необходимо заметить, что в стране существует Академия наук, а при ней - многочисленные центральные и местные экологические, геологические, биологические и др. учреждения, которые почему-то не привлекаются к решению профильных задач.

Озеро Байкал как ОВПН с 1996 г. находится также под международным правовым регулированием. Например, на 39-й сессии ЮНЕСКО (Бонн, 2015) было выражено «сожаление», что Россия не представила отчет о состоянии сохран-

\footnotetext{
${ }^{1}$ https://regnum.ru/news/2602456.html (проверено 27.10.2019).
} 
ности озера Байкал, который был запрошен по решению 38-й сессии (Доха, 2014). Затем в течение последних 3 сессий в 2016-2018 гг. Комитет всемирного наследия ЮНЕСКО постоянно выражал «озабоченность» и «большую озабоченность» относительно экологического состояния ОВПН озера Байкал, а именно изменение экосистемы, цветение водорослей, снижение рыбных запасов, колебание уровня воды в озере и др. Комитет всемирного наследия на каждой сессии рекомендовал России как стране, на территории которой находится ОВПН, выполнить определенные работы. На 42-й сессии ЮНЕСКО в июле 2018 г. (Бахрейн) уже был указан конкретный срок, к которому Россия должна отчитаться о принятых мерах по выполнению рекомендаций ЮНЕСКО по сохранению и об актуальном состоянии сохранения озера Байкал, -1 декабря 2019 г. Таким образом, невыполнение требований ЮНЕСКО к концу текущего года будет еще одним ударом не только по судьбе Байкала, но и по международному престижу России.

Подводя итог, можно констатировать, что у «священного моря» существуют многочисленные проблемы, которые, в свою очередь, вызывают такие же многочисленные вопросы.

Действительно ли Байкал является «священным», или или это только постоянный источник дополнительного дохода для сменяющих друг друга бесчисленных временщиков?

Почему вдруг провал еще одной, формально действующей ФЦП по сохранению Байкала (2012-2020 гг.) вызвал такой интерес и возмущение в обществе? Ведь открывались и закрывались десятки ФЦП по другим вопросам, которые заканчивались только многотомными отчетами. Наверное, потому что исполнители этой ФЦП по очистке Байкала слишком явно, слишком энергично вели программу к провалу. Да и сама тема Байкала слишком болезненна, чтобы промолчать или сделать вид, что все нормально.

В мутнеющих водах Байкала, как в зеркале, начали четко отражаться социальные проблемы общества: некомпетентность, неисполнительность, бескультурье, правовой нигилизм и привычная уже коррупция.

\section{WHY THE «SACRED BAIKAL» IS NOT PURIFICATED?}

Abstract. The article discusses the status, causes and sources of existing environmental problems, topical issues of conservation of the world natural heritage site - the Lake Baikal, the implementation of the federal target program «Protection of the Lake Baikal and socio-economic development of the Baikal natural area for 2012-2020».

Keywords: Lake Baikal, world natural heritage site, fresh water, pollution, Federal target program 